\title{
"A FAPEAM é um patrimônio nosso" José Aldemir de Oliveira: um cidadão amazônico
}

\author{
Por George REBÊLO ${ }^{1}$ e Ana Paula FREIRE ${ }^{2}$
}

Com uma carreira científica respeitável, o professor José Aldemir de Oliveira, 51 anos, da Universidade Federal do Amazonas (UFAM), assumiu a difícil missão de implementar a Fundação de Amparo à Pesquisa do Estado do Amazonas - FAPEAM. Ficou dois anos e meio e se afastou por problemas de saúde. Natural do Alto Careiro, veio para Manaus estudar, formou-se em geografia e, desde 1976, tem se dedicado ao magistério. Ingressou na UFAM em 1985, como professor colaborador, e três anos mais tarde entrou para o quadro efetivo da instituição. Fez pós-graduação em Geografia na Universidade de São Paulo (USP), onde iniciou o mestrado em meados de 90, e, em apenas um ano, migrou direto para doutorado, retornando à UFAM quatro anos depois com a tese defendida. Construiu sua carreira pensando na Amazônia, na perspectiva de contribuir para o desenvolvimento regional. A tese, "Cidade na selva: urbanização das amazonas", é um estudo das espacialidades amazônicas, cuja proposta é compreender como as cidades sofreram os impactos da política "desenvol-vimentista" para a Amazônia, a partir da implantação do Polo Industrial da Zona Franca de Manaus (ZFM). Essa pesquisa resultou no livro "Cidades na selva" (2000), que não é a tese propriamente dita, mas que tem como base os estudos realizados no doutorado. Em seguida, publicou "Manaus, de 1920-1967: a cidade doce e dura em excesso", em que analisa as espacialidades da cidade em crise. É a capital amazonense, aliás, que tem sido, desde então, o objeto de estudos do núcleo coordenado por José Aldemir, na UFAM. Este homem, com seu jeito de falar simples e correto, revolucionou o sistema de financiamento à ciência e tecnologia na Amazônia ocidental, em pleno século XXI. Como um visionário, se faz entender com clareza. No dia 12 de setembro passado, em uma conversa que durou quase três horas, José Aldemir de Oliveira concedeu a seguinte entrevista para a Acta Amazonica.

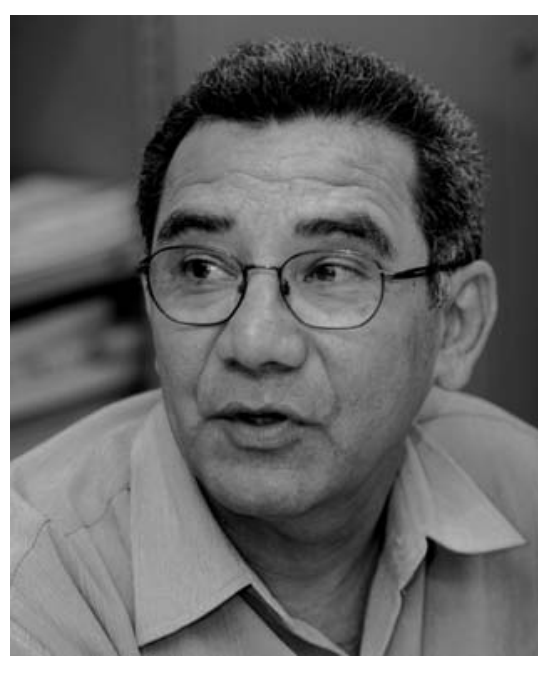

\section{Sou um cidadão amazônico. Quando nasci, era Careiro. Hoje, o lugar é Manacapuru, já foi Manaquiri. Meu pai ainda mora lá.}

JoséAldemir de Oliveira

\footnotetext{
${ }^{1}$ Editor-chefe Acta Amazonica, INPA. Caixa Postal 478, 69011-970, Manaus-AM: jacare@inpa.gov.br

${ }^{2}$ Jornalista, Divisão de Comunicação Social, INPA. Caixa Postal 478, 69011-970, Manaus-AM: anap@inpa.gov.br
} 


\section{ACTA \\ AMAZONICA}

"A FAPEAM É UM PATRIMÔNIO NOSSO"

JOSÉ ALDEMIR DE OLIVEIRA: UM CIDADÃO AMAZÔNICO

\section{Podemos começar pedindo para que faça um retrospecto do seu percurso acadêmico.}

Eu sou geógrafo de formação e fiz minha pós-graduação pensando na Amazônia, mais em uma perspectiva do desenvolvimento regional e, no transcurso do mestrado migrei para cidade. Na USP, eu passei a me dedicar mais à questão das cidades, sobretudo na linha da nova escola, da nova história, digamos, uma geografia do cotidiano. A tese já era um pouco nesse rumo, de buscar não compreender as espacialidades amazônicas pelas grandes estruturas, mas compreender a partir da vida simples. A minha tese é sobre pequenas cidades. Em relaçãoà Amazônia, a idéia era comparar esse processo de fora com o que ocorre no surgimento dessa espacialidade. Eu tenho como matriz teórica Henri Lefevbre, que trabalha a perspesctiva do espaço numa visão de uma tríade, que me parece se encaixar muito bem para a Amazônia. Isso quer dizer: as espacialidades, ao serem postas em determinados lugares, aniquilam as espacialidades presentes, mas não aniquilam completamente, porque esses resíduos geram a resistência, que geram novas espacialidades. Isso se coadunou numa análise diferente das espacialidades na Amazônia, que não podem ser vistas apenas como uma perda, mas também como uma nova configuração, um novo espaço uma nova vida. Como cientistas, nós temos sobretudo que coomprender esse processo, e, como cidadão, estabelecer um juízo de valor: se eles são bons ou ruins. Enfim, a visão maior é compreender como essa política "desenvolvimentista" para Amazônia, a partir de 64 (com o golpe militar ou a "revolução" de 1964), gerou os novos núcleos urbanos. A pesquisa durou quatro anos, entre créditos e pesquisa, e dessa pesquisa gerou um livro-Cidades na Selva (2000), que não é a tese, propriamente dita, mas um livro que demorou um bom tempo para ser concluído: seis anos. O livro é uma tentativa de compreender como essas cidades, esses núcleos na Amazônia são criados.

E aí as dificuldades de financiamento de pesquisas fizeram com que eu passasse a me preocupar com Manaus. Então, nós temos um projeto em andamento, desde 95, que é para compreender um processo grande, que é a transformação e a permanência de Manaus, dividido em três fases.

Na primeira fase, nós pegamos a partir do momento que tem pouca bibliografia sobre a cidade, que são os anos 20 , que é quando vem a crise da borracha. Aí pegamos de 20 a 67, que é quando se fala na Zona Franca; de 67 a 2000, e de 2000 até quando o projeto tiver fechando. E esse de 20 a 67 , fechando, gerou um livrinho chamado "Manaus, de 1920-1967: a cidade doce e dura em excesso", quando a gente analisa as espacialidades da cidade em crise, colocando em xeque essa fase, porque foi um período em que a cidade tinha muitos cinemas, teatros, um vida cultural muito interessante, festas, bailes, etc., embora, do ponto de vista das políticas públicas e das finanças públicas, tenha sido realmente um período de "deblache". E o período de 68 a 2000, começou a ser feito no final de 2002, aí teve essa interrupção grande, e agora estamos reorganizando a equipe, reorganizando o grupo, para gerar dissertações etc., para que talvez, no final do próximo ano nós tenhamos esse segundo volume, que é sobre Manaus, da Zona franca para cá, da Zona Franca até 2000 . E outro, depois, é a cidade do século 21.

\section{Manaus hoje é a maior cidade da Amazônia central...}

Manaus é a maior cidade do Brasil que não está inserida numa região metropolitana. Esse é um dos nossos temas do simpósio (IX Simpósio Nacional de Geografia Urbana SIMPURB, realizado em Manaus entre 18-22 de outubro de 2005) para que nós, talvez, venhamos desenvolver um projeto articulado possivelmente, e com outras universidades, onde nós possamos analisar as diferenças e as similaridades entre ter uma cidade de quase dois milhões de habitantes, isolada, que não faz parte de uma região metropolitana. O que tem de diferente e o que tem de similar com uma região metropolitana? Porque as outras cidades com mais de 1,5 milhões de habitantes estão sempre inseridas numa região metropolitana.

\section{Muitas pessoas que não conhecem a Amazônia acham que Manaus e Belém são parecidas, mas são muito diferentes, não?}

Sim, são diferentes. Primeiro, nós, geógrafos, entendemos que os espaços são também influenciados pelas coisas da natureza. Os espaços se constituem pelas coisas da natureza e pelo que dispõem os homens. Então, o fato de ter uma cidade próxima ao oceano e outra cidade para o interior, isso tem diferenciações significativas. Do ponto de vista do projeto urbanístico, como foi se desenrolando a cidade, o que acontece: Belém tem um centro que, de certa forma, vai ser capturado por uma verticalização, mas ficaram alguns nichos bastante preservados. Além disso, você tem uma rede de instituições que formou uma espécie de arco. Ou seja, você pega a planta de Belém, tem a Federal (UFPA), a Aeronáutica, a Marinha, como que fazendo um cinturão que protege essa parte. Aí tem a cidade para frente. Isso foi tentado para Manaus: fazer, aqui, a Aeronáutica, a Base Aérea, começa com campus, com o INPA, e queria se criar uma área militar contínua àquela área do INPA, pelo V-8 (Av. Efigênio Sales), e que iria até a beira do rio. Então, sairia da Ponta Pelada, dava esse circuito, até os militares da Ponta Negra, como proteção, digamos assim, mais institucional, que garantiria uma preservação ambiental. Porque, se há uma característica da nossa cidade, de Manaus, é fato de que ela sai, sem o intermédio da floresta, para o asfalto. E isso tem implicações de ordem ambiental bastante significativas e que precisam ser melhor dimensionadas. Se você tem uma cidade com pouquíssima ou quase nenhuma área verde, dessa área mais central, tem o campus do INPA, e aí vai se variando, aquela área militar, que realmente é uma área razoavelmente preservada, e nada mais. 


\section{ACTA AMAZONICA}

"A FAPEAM É UM PATRIMÔNIO NOSSO" JOSÉ ALDEMIR DE OLIVEIRA: UM CIDADÃO AMAZÔNICO

\section{Tem a Reserva Ducke, que está sendo cercada pela cidade...}

Ainda bem que se criou aquela forma de proteção, porque se não aquilo também iria desaparecer. Agora, até por conta desse projeto, existe a proposta de criar um parque na cabeceira do (Parque do) Mindu. Porque tem um outro problema: o Estado está fazendo uma intervenção razoável no Igarapé do 40, o problema é que não é apenas ali. E lá em cima, como é que faz? você pode arrumar aqui embaixo e, enfim... Essas diferenças são fundamentais, do ponto das espacialidades, entre Belém e Manaus. Belém é uma cidade cuja parte central está muito mais preservada do que Manaus.

Isso se reflete na questão cultural. Por exemplo, no entorno do Teatro da Paz, em Belém, há uma vida cultural intensa.

Em Manaus, agora é que se vem trabalhando a cultura nas proximidades do Teatro Amazonas. É só um exemplo...

Com certeza. São questões diretamente ligadas.

\section{O isolamento de Manaus se coloca como um possível obstáculo para os nossos pesquisadores, as nossas competências, se firmarem no cenário intelectual nacional? Qual a sua avaliação sobre isso?}

A minha visão é um pouco diferente. Eu entendo que a construção de uma carreira fora do grande centro talvez seja menos difícil do que nos grandes centros, porque, primeiro, nós temos possibilidades de pesquisas muito mais interessantes, do ponto de vista científico e do ponto de vista, no caso das Ciências Humanas, de um resultado para a população. Todos os estudos são importantes, mas, por exemplo, se eu me dedicasse a estudar como é que as novelas abordam o urbano, isso é muito importante para compreender a sociedade brasileira. Mas isso talvez tivesse menos repercussão para a sociedade, do que, por exemplo, como a gente faz aqui, que a gente estuda as espacialidades das cidades, como é que se ocupam os igarapés, a questão do transporte urbano... a gente tem um projeto interessante, de uma aluna muito promissora, com as invasões, ou seja, são pesquisas de maior interesse da sociedade. Quando você está no grande centro, até pela competição entre os pesquisadores, em uma área como a minha, por exemplo, quase tudo foi estudado. O que eu iria estudar na cidade de São Paulo? Então, eu vejo os geógrafos da minha geração, que se formaram nos anos 1990, estudando um tema que aqui na Amazônia não teria tanta importância. Por outro lado, hoje, com a Internet, com as possibilidades, e aí já entra um pouco a nossa conversa sobre o financiamento de ciência e tecnologia com as instituições que se criam fora desses eixos, com a possibilidades que nós temos de acesso ao financiamento de pesquisa pelas agências nacionais, isso possibilita que possa ir a pelo menos dois eventos nacionais por ano; possibilita que o pesquisador tenha material para submeter a duas revistas nacionais e internacionais por ano; possibilita construir uma carreira acadêmica fora dos grandes centros que não deixa muito a desejar, isso em uma área como a minha. Diferente de outras áreas como saúde, e outras, que precisam de computadores de última geração, por exemplo. Eu tenho convicção de que se constrói uma carreira numa área de geografia na região, fora do grande centro tão boa como nos grandes centros. Nós temos, hoje, na área de geografia, no

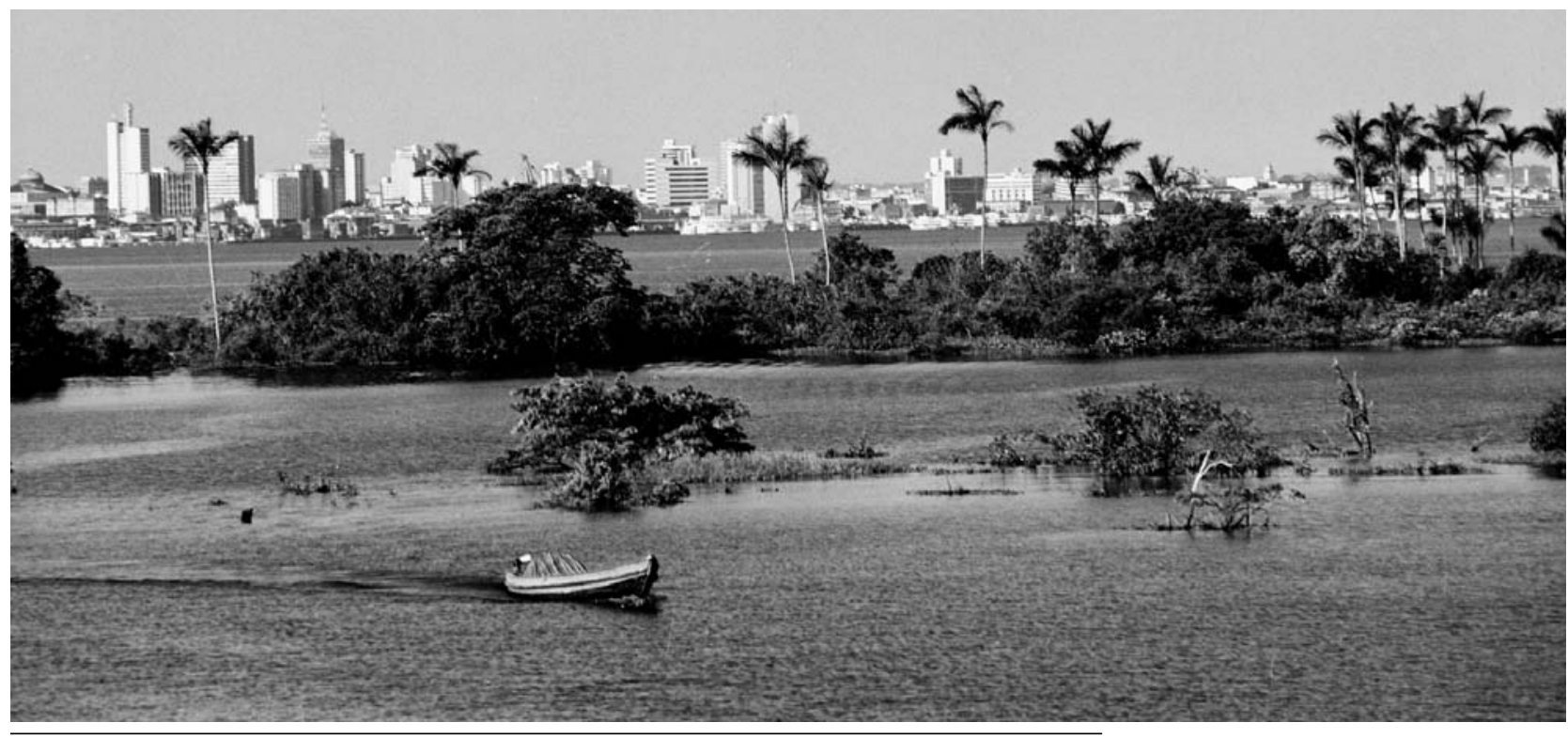

Foto - Ricardo Oliveira 
Brasil, o maior geógrafo vivo, que é o Manuel Correia de Andrade, que é de Pernambuco [o maior era o Milton Santos, que construiu carreira em grande centro, mas era baiano]. $\mathrm{Na}$ área de geografia urbana, nós temos uma boa produção na região Norte, aqui, e alguns colegas de Belém.

\section{Falando de financiamento, tema principal da nossa conversa, o senhor poderia fazer um retrospecto da sua entrada na FAPEAM, desde o início, como foi o convite, até a saída...}

Eu fui convidado para FAPEAM por conta de costura política. Na realidade, eu fui como membro filiado do Partido dos Trabalhadores (PT). Creio que devo ter feito lá uma gestão para além disso. Em nenhum momento passou por perto a idéia de que a minha origem tivesse a ver com o meu trabalho lá [ na FAPEAM] . Obviamente, quando fui convidado, primeiro me espantei, porque construí minha vida toda na universidade, no ensino. Porém, a gente sempre acha que pode dar uma contribuição e era um sonho de muito tempo da comunidade científica do Estado, de ter uma instituição que pudesse, num estado como o nosso, com as ingerências políticas que nós temos, com uma certa autonomia, privilegiar a qualidade, a meritocracia, etc. Aí, nós fomos. O desafio era monstruoso, porque a FAPEAM, entre março e junho de 2003, era apenas um microcomputador, não tinha nada. E aí a gente começou a construir desde o estatuto da instituição, até montar a estrutura de funcionários, enfim, colocar a FAPEAM para andar. Nós - eu digo nós porque era uma equipe - convidamos professores da universidade, sempre com a preocupação de levar pessoas de várias áreas, entre elas, a professora Nídia Fabré, da área de biológicas, a professora Elizabeth Brocki, da área de tecnologia da UEA [Universidade do Estado do Amazonas], a professora Sidnéia Amadio, que é do INPA. Além disso, tínhamos um corpo de assessores também com essa perspectiva, de uma equipe multidisciplinar. E aí foi muito interessante porque algumas pessoas participaram da FAPEAM.

Como disse, nós fomos montando a equipe de funcionários tentando trazer pessoas de algumas instituições, e, quando chegamos no mês de junho, estávamos diante do seguinte impasse: ou estruturávamos bem a instituição em termos de nós termos clareza dos processos, de como fazer, analisar e testar. - e isso implicaria que nós só teríamos os primeiros financiamentos em 2004 - ou nós, um pouco no escuro, começávamos a fazer os primeiros financiamentos. Por quê? Porque havia recursos orçamentários, quando nós chegamos lá, na ordem de 15 milhões de reais. Que foi diminuindo, diminuindo, porque, obviamente, se tem uma dotação orçamentária e um Estado como cobertor curto, ele não vai sendo usando e vai sendo levado para outras áreas. Eaí, quando chegou em 9 milhões de reais, olha, 9 milhões de reais num estado como o nosso, dá para se fazer muita coisa, aí nós chegamos até a conversar com alguns pesquisadores, dizendo dessa nossa preocupação, porque entendíamos que o Estado queria financiar a pesquisa como quem financia uma ponte. $\mathrm{Ou}$ seja, o processo é o mesmo. As primeiras bolsas que nós concedemos na FAPEAM, queriam fazer licitação da bolsa. Aí, eu ponderei que isso não era possível, mas se nós pegarmos os primeiros processos, vamos ver que tem lá tem um carimbo da Comissão Geral de Licitação dispensando a licitação. E eu espero que essa história da FAPEAM ainda seja resgatada.

\section{E como foi esse momento?}

Inesquecível. Nós resolvemos fazer, abrimos edital, animamos, dividimos com a comunidade a escolha do projetos. Nós fizemos algo inédito no Brasil: que as pessoas votassem livremente nos membros da Câmara [de Assessoramento Científico]. Foi eleição, uma festa lá na FAPEAM, escolhemos a Câmara, com alguns problemas, mas, enfim, a comunidade escolheu, depois, trouxemos pessoas de fora porque a nossa comunidade científica ainda é muito pequena, e resolvemos que essa avaliação [dos projetos de pesquisa] se daria também com pessoas de fora e assim foi.

\section{E sua atuação, como presidente?}

No tempo que eu permaneci na FAPEAM, com a exceção de um caso, de uma passagem aérea, o presidente nunca interveio em absolutamente nada, para onde ia, para onde deixava de ir. Tudo, de uma passagem aérea a um evento - e eu tenho conhecimento de que continua assim - é feito publicamente, edital aberto, todos concorrem com direito de reclamar, de recorrer, etc.

\section{E quanto aos recursos?}

Bem, aí, em 2003, nós conseguimos colocar na mão dos pesquisadores 3 milhões de reais, ou seja, saímos de zero para três milhões. Em 2004, a nossa perspectiva era atingir os 100\% do orçamento da FAPEAM. Mas as instituições, principalmente aquelas que estão iniciando, elas dependem muito das pessoas ainda. E, aí, em maio de 2004, eu tive um problema seríssimo e me afastei da FAPEAM o resto do ano. Fiquei oito meses fora da instituição. Tivemos alguns problemas, mas, mesmo assim, honramos os compromissos assumidos. Ao mesmo tempo, criamos outros. A instituição soltou novos editais. E, no primeiro semestre de 2005, foi um ano de avaliar os projetos, as primeiras ações, mas sempre com a perspectiva de valorizar o pesquisador em primeiro lugar. Tanto que em nossas ações, com muito risco do ponto de vista institucional, os recursos são repassados direto para o pesquisador, direto para o coordenador, como uma forma de descentralizar recursos e sobretudo na perspectiva de acreditar nas pessoas.

\section{E vem dando certo?}

Olha, a burocracia do Estado Brasileiro é organizada no sentido de que todos são culpados antes que prove o contrário. 


\section{ACTA AMAZONICA}

"A FAPEAM É UM PATRIMÔNIO NOSSO" JOSÉ ALDEMIR DE OLIVEIRA: UM CIDADÃO AMAZÔNICO
A nossa perspectiva é inverter isso, confiar nas pessoas, confiar nos pesquisadores e repassar os recursos para eles. Os resultados, até junho, quando eu estava lá, eu diria para você que o percentual dos problemas que tivemos na aplicação dos recursos não chega a ordem de $2 \%$. Bastante baixo, se comparado, por exemplo, à inadimplência no setor financeiro, dos bancos privados, por exemplo.

A FAPEAM é um divisor de águas na
pesquisa na Amazônia. Vocês criaram a
FAPEAM e se estabeleceu um marco na
pesquisa científica no Estado do
Amazonas, mas com desdobramentos
em toda a Amazônia (a ponto de
pesquisadores de outros estados estarem
maravilhados com esse evento que
aconteceu aqui), que sugestões você
daria para quem precisa sair do zero,
como outros estados da Amazônia que
precisam sair do zero e criar uma FAP,
comunidades científicas que estão se
estruturando, que erros e acertos vocês
cometeram e não cometeriam de novo?

Primeiro que num Estado como o nosso, no estado Brasileiro e não apenas no Amazonas, é sempre um conjunto de fatores que leva a criação de uma FAP. No caso especifico nosso, havia o comprometimento do governador [Eduardo Braga, atual governador do Amazonas], durante a campanha, de que implantaria a FAPEAM.

\section{Que era prevista...}

Isso, que já estava constituída desde 1989 e foi efetivamente criada em 2002. Em julho de 2002, a Assembléia Lesgislativa aprova a criação da FAPEAM o então candidato ao governo, Eduardo Braga, promete implementá-la, se eleito. Além disso, nós temos um conjunto de instituições no Estado com pesquisadores pressionando para que isso ocorresse. $\mathrm{O}$ começo deve ser feito, na medida do possível, por pessoas que acreditem na produção do conhecimento como um bem para sociedade, e que veja, nessa oportunidade, um exercício para nós, da academia, como exercício da coisa publica até como exemplo para outras instituições. Quando nós saimos da FAPEAM, não foram poucos os outros agentes que se espantavam quando, por exemplo, nós conseguíamos trazer para Manaus consultores do mais alto gabarito, em cada área de conhecimento, e essas pessoas vinham para cá, analisar projetos, ficar conosco às vezes uma semana a custo zero para a instituição.

\section{E a que você atribui o interesse dessas pessoas?}

Ao simples fato de que elas acreditavam na proposta. Então, a primeira questão é essa: tratar a gestão - isso deveria ser na gestão publica de um modo geral - mas, no caso nosso, de ciência, muito mais ainda com respeito ao bem público. Porque nós somos, queiramos ou não, um grupo que pensa na sociedade. Então, nós temos obrigação de fazer diferente, de mostrar que é possível fazer diferente. Por isso, eu acredito muito nas pessoas que continuaram na FAPEAM. Eu saí por problemas de saúde - as pessoas sabem disso, mas é bom reafirmar -, não podia continuar. Mas, se isso for tratado dessa forma, é possível que você não tenha ingerência política. Eu diria para vocês que, nos dois anos e meio que fiquei na FAPEAM, nunca tivemos, nem de longe, qualquer interferência política. Todos os processos são processos técnicos. O que há de interferência política é salutar e deve existir. As determinações gerais vem de uma política de governo. Ou seja, a prioridade da FAPEAM será financiar isso..isso..isso... Terminou essa diretriz, os processos deve ser claramente conhecidos por todos, amplamente discutidos na comunidade, e seguidos rigorosamente, para que, depois, você possa cobrar também resultados. Porque nós não podemos esquecer que estamos num Estado que ainda tem inúmeros problemas para serem resolvidos. E a nossa ação, como pesquisadores, é de apontar para a produção de um conhecimento que possa servir para a sociedade. Isso não quer dizer que tenha que se fazer só pesquisa aplicada. Eu quero dizer também que, mesmo quando fazemos pesquisas básicas, essas pesquisas devem ter compromisso social. O que é o compromisso social? Cumprindo com o que nos comprometemos nos projetos, com o que nós nos comprometemos na formação de recursos humanos. Não quero dizer que isso tem que ser algo para se resolver um gargalo tecnológico, não é isso. Mas que tem que ter um compromisso social de se fazer e se fazer bem feito.

\section{Você mencionou dois aspectos interessantes: a questão da autonomia e da dependência que novas instituições têm das pessoas. Você acredita que a FAPEAM esteja consolidada e andará com as próprias pernas, independentemente de quem esteja no Governo, ou será que é possível a vinda de um governante que não tenha a mesma visão, que esse projeto seja interrompido?}

A FAPEAM é muito nova, é uma instituição engatinhando. Eu diria que, hoje, a bola está com os pesquisadores. Por que? 


\section{ACTA \\ AMAZONICA}

"A FAPEAM É UM PATRIMÔNIO NOSSO"

JOSÉ ALDEMIR DE OLIVEIRA: UM CIDADÃO AMAZÔNICO
Porque depende muito deles. A FAPEAM, até a minha saída, tinha colocado no sistema de ciência e tecnologia no Estado, algo cocmo 35 milhões de reais, nos dois anos e meio. Esse valor já deve ter sido ultrapassado. E, desses projetos, só um em programa tínhamos chegado na fase de relatórios, que é o Jovem Cientista Amazônico, com resultados muito positivos. Então, o resultado das pesquisas, as formas como elas forem prestadas contas à sociedade, o pesquisador que ter em mente que a FAPEAM não é o diretor que lá está, não é o governador do momento. A FAPEAM é um patrimônio nosso. Portanto, eu devo ter orgulho de dizer: o meu projeto tem financiamento da FAPEAM. Nós nos debatíamos muito porque, em alguns casos, tínhamos projetos financiados e os pesquisadores não informavam - não é informar para o presidente, para o diretor de sua instituição - mas informar à sociedade que o seu dinheiro está empregado aqui, está dando esses resultados. Isso é algo importante, você tem que falar com o seu deputado que a FAPEAM é algo que deve continuar. Este lobby, no sentido positivo, dos pesquisadores, deve continuar. Nós devemos estar sempre atentos porque as instituições do nosso País são muito frágeis ainda. Obviamente, ninguém, hoje, vai tentar acabar com a Fapesp [Fundação de Amparo à Pesquisa do Estado de São Paulo]. Mas você tem outras FAPs no Brasil que eram muito boas que tiveram problemas políticos seriíssimos, e quase fecharam. Eu não conhecia pessoalmente - conhecia como político, o governador [Eduardo Braga] - mas acredito que ele teve uma atuação, com a FAPEAM, muito digna, do primeiro ao último dia que eu estive lá, e, efetivamente, que nós erramos, erramos em conta de nossa dificuldades, dos nossos limites, mas não porque houvesse ingerências políticas. É claro e evidente que todo gestor público gostaria de que tivesse uma dotação orçamentária e que essa dotação orçamentária se transformasse em dotação financeira. Mas isso não existe no Estado Brasileiro. No começo, eu ficava muito angustiado, mas, no final, já tinha aprendido isso. Precisava estar 24 horas atento para que o recurso saísse no prazo marcado e eu tenho muita esperança de que, no final de 2006, nós tenhamos a autonomia financeira da FAPEAM. É um processo.

\section{A Amazônia é uma região singular, obviamente, com problemas bem peculiares. Mas, entre os diversos avanços com a chegada da FAPEAM, citamos o olhar para as populações indígenas. Poderia falar sobre isso?}

Nós queríamos marcar um pouco a passagem por lá. Não eu, mas a equipe. O que uma FAP faz? Uma FAP financia bolsas, projetos, eventos, publicações etc. Pensávamos assim: nós vamos fazer isso, mas vamos criar um projeto que é a nossa cara. Desde o momento em que nós fomos convidados, que eu chamei algumas pessoas para pensar a FAPEAM, vinha essa idéia: nós temos que ter algo que seja a cara da Amazônia. E eu sempre pensava em ciência numa perspectiva de desmistificála no sentido de torná-la mais acessível à população. De várias conversas surgiu a idéia de criarmos esse programa Jovem Cientista Amazônico, que tem como base, o núcleo de pesquisa, ou seja, o pesquisador é o centro do processo, ele que articula uma comunidade indígena, ou ribeirinha, ou de periferia urbana - e outro edital que estava sendo discutido visando contemplar as sociedades extrativistas - e, com aquiescência dele, montase o projeto, que não é um projeto do INPA, é um projeto do INPA e da comunidade, executado por um pesquisador.

\section{Esse programa, então, é um diferencial da FAPEAM?}

Sim, porque criamos também o mecanismo de valorizar toda a pesquisa. Ou seja, é o único projeto da FAPEAM em que toda equipe é remunerada. Há os voluntários, mas o pesquisador tem uma bolsa, que é simbólica, mas nós queríamos, mesmo assim, oferecê-la. E envolve alunos de mestrado, de iniciação científica, e envolve um professor, que pode ser até duas escolas, dois professores, e alunos da escola. Mas nós não queríamos que esses alunos fossem o carregador da pasta ou o que vai limpar o laboratório. Queríamos que ele realmente participasse do projeto, fizesse tarefas inerentes à sua capacidade cognitiva, e o resultado é muito positivo principalmente porque só a FAP do Amazonas faz isso, não há nem uma outra no Brasil, nem o CNPq faz, nem a CAPES faz. É um fator diferencial, sem dúvida. E com boa avaliação.

\section{E qual o feedback que a FAPEAM tem dos que são beneficiados pelo projeto?}

Veja, uma vez recebi um telefonema de um deputado cobrando por que a FAPEAM atrasava as bolsas. Eu disse: porque a SEFAZ [Secretaria de Estado da Fazenda] não repassa os recursos. Perguntei-lhe quem havia reclamado e ele me disse que havia sido uma pessoa do interior. Aí, eu perguntei: eu posso marcar uma audiência? Pode, ele disse. Aproveitei, me municiei de pacotes e fui lá no gabinete do deputado. Ele me atendeu e não conhecia a FAPEAM. E aí eu expliquei e indaguei: mas como é? Me conte essa história do seu eleitor que reclamou na bolsa. Ele disse que, certa vez, estava em Tefé [pequena cidade no Rio Solimões/Amazonas $600 \mathrm{~km}$ rio acima de Manaus] e, em uma comunidade lá, uma senhora chegou e disse: "vê se você dá um jeito nessa senhora FAPEAM, pra ela pagar direito a bolsa do meu filho, porque lá em casa éo único dinbeiro que entra certo todo mês". Era 80 reais. E, dessa conversa com o deputado, ele imediatamente fez um requerimento e eu fui na Assembléia, naquelas sessões especiais, explicar o que era a FAPEAM, e falar basicamente sobre esse projeto. E esse deputado, que eu não vou citar aqui, foi um dos maiores defensores da FAPEAM. Porque se há uma ação governamental que gera boas notícias, isso gera votos para eles. Por mais que não estejam interessados em construir um projeto perene para a sociedade, mas se aquilo gera boas informações, acaba atendendo aos interesses imediatos deles e atendendo aos nossos interesses, como pesquisadores, que são interesses mais de futuro. Sem resultados a curtos prazos, 


\section{ACTA \\ AMAZONICA}

"A FAPEAM É UM PATRIMÔNIO NOSSO"

JOSÉ ALDEMIR DE OLIVEIRA: UM CIDADÃO AMAZÔNICO

sem que essas pesquisas apresentem resultados, aí, sim, nós corremos um risco.

\section{Como é a sensação de deixar "o filho que viu nascer e ajudou a dar os primeiros passos", considerando que a sua saída foi involuntária porque teve problemas de saúde... Enfim, você sai de alma lavada, sai triste, qual é a sensação?}

Usando uma expressão bem popular, eu saí de fininho (risos). Na realidade, quando souberam, eu já estava fora, não teve nem despedida. Agora, a eu saio assim: primeiro, com o prazer te ter participado desse projeto; segundo, com um respeito muito grande aos pesquisadores do Estado. Eles nunca nos faltaram, eles foram compreensivos, mesmo com erros nossos, às vezes alguns erros grotescos. Mas nós os reconhecemos e procuramos solucioná-los dentros das nossas possibilidades. Então, o fato de as pessoas se referirem ao nosso trabalho como um trabalho direito, isso acaba compensando essa tristeza de ter saído em determinado momento. Por outro lado, minha vida é na universidade. Não sei fazer outra coisa além disso e eu queria muito voltar. Eu estou formando gente de novo, todos esses alunos são do primeiro período da Geografia. Quero começar de novo a formar gente, ter um grupo de novo. Porque, nesses dois anos e meio, a gente teve como princípio não pegar financiamento da FAPEAM, então precisávamos voltar para universidade e firmar um grupo para buscar financiamento. Então, não sinto muito esse sentimento de perda. E tenho a clareza de que as instituições são mais importantes do que as pessoas. Se eu não tivesse ido para lá, outro teria ido,talvez até fosse melhor.

\section{A que erros se referiu há pouco?}

Teve um caso de uma pesquisadora do INPA, que tinha um financiamento que não era muito volumoso e que, por um erro no processo, tira do projeto dela metade do valor. Quando paga o processo todo - por exemplo, metade era custeio e metade era capital - um ou outro desaparece e só passa uma das partes dos recursos para ela. E ela recebe os recursos e aí diminuiu tanto o valor que, na hora de processar, nós dissemos: paga logo $100 \%$. E foi paga somente a metade dos recursos. Para ela, no entanto, havíamos pago a metade do projeto. E ela honrou com todos os seus compromissos, sua pesquisa. Depois, como não veio o resto do dinheiro, ela questionou, com razão. Mas nós não havíamos percebido o erro e chegamos a afirmar que o projeto que ela havia aprovado era naquele valor, equivalente à metade e não à totalidade real. Eu sei que erros dessa natureza ocorrem porque a burocracia do Estadoé pesadíssima. As pessoas podem pensar: ah, coloca esse valorera 17 mil - de volta e resolve o problema. Mas, para colocar esses 17 mil para essa professora eu passei quase um ano. E ela tinha comprado equipamentos e eu ligava direto para o fornecedor. Ele já não queria mais saber, queria mandar o cheque da professora para protestar e ela estava apavorada porque não tinha como bancar isso. Por outro lado, os equipamentos já estavam no laboratório. Enfim, foi um problema causado por um erro nosso, mas que a pesquisadora teve o entendimento de que não havíamos agido de má fé. Ela não colocou isso a público, não foi para a Imprensa, ela nem discutiu com seus pares porque ela percebia que fora um erro grotesco, foi uma incompetência nossa, mas não era má fé. E que nós queríamos solucionar e que a solução não era impossível. Esse foi um caso.

\section{Houve algum outro?}

Um outro caso, uma outra instituição, recebeu um repasse institucional e, por qualquer motivo, caiu numa conta, naquela conta do sistema federal que eles não conseguem gastar o dinheiro. A solução seria devolver o dinheiro, mas o Tribunal [de Contas da União] disse que não seria possível devolver o dinheiro. Tem que pagar juros e etc. Isso ainda não foi resolvido, é um processo longo, a instituição tinha gasto, por conta desse projeto, metade do dinheiro que nós repassamos, sem usar o dinheiro da FAPEAM. E está lá, como se aquilo tivesse sido financiado pela FAPEAM. Enviamos um pacote de relatórios e pedimos que considerassem isso como juros. Caso contrário, a única forma de pagar seria o dirigente tirar o recurso de seu próprio bolso, o que não seria o caso. Mesmo assim, a instituição não criou caso, embora, nesse caso, o erro tenha sido compartilhado. Então, nós nunca tivemos alguém na mídia dizendo que seu projeto não foi aprovado. Mesmo porque, se dissessem isso, a própria comunidade diria que não.

\section{A que atribui essa tolerância?}

Eu acho assim: quando as coisas são feitas às claras, por mais que existam erros, no caso da pesquisadora, nós assumimos o erro, mesmo sabendo que não podíamos errar. Mas não adiantava pegar o funcionário que errou e mandá-lo embora, porque ele vive disso. E eu tenho certeza de que ele não errou porque quis errar. Então, houve uma grande contribuição da comunidade e sem contar algo que é muito para quem faz as coisas, o sentimento humano. Embora eu não faça disso uma bandeira, nunca usei a instituição para absolutamente nada, o fato de dizerem assim: eles fizeram um trabalho direito, isso também, como disse antes, acaba por compensar a tristeza de ter saído da FAPEAM quando ela engrenava.

\footnotetext{
Você falou há pouco na perspectiva de "desmistificar" a ciência. Você acha que um dos caminhos é a popularização do conhecimento científico, por meio de outras ações? Como avalia isso?
} 


\begin{abstract}
Acho que a primeira questão é: o cientista de hoje, o cientista do nosso tempo, do nosso agora, é um ser importantíssimo para sociedade, mas ele não é um semi-deus. Essa é a primeira questão. Isso significa dizer que seus projetos, seus processos têm limites, têm erros, e, portanto, ele tem que submeter a quem o financia, que é a sociedade. Não
\end{abstract} é o governo Eduardo Braga que financia, não é governo Lula que financia. É a sociedade que financia. Ele não tem que ter compromisso com o governo A e B, ele tem compromisso com a sociedade e, por isso, tem que prestar conta. Esse prestar conta não é com recibo, não. É com resultado. Não existe, na minha opinião, uma pesquisa que não seja importante para sociedade, todas são. Agora, no mínimo, a sociedade deve saber que está sendo feito. Eu debatia na FAPEAM e hoje eu creio que o professor Odenildo [Sena, atual presidente da FAPEAM] está pensando nisso, de se criar uma linha de jornalismo científico na nossa região. Porque é necessário que a gente coloque numa linguagem acessível à população o que está sendo pesquisado. Até para desmistificar. Veja o caso de uma instituição que eu conheci melhor indo para a FAPEAM, que é o INPA. O INPA tem inúmeros trabalhos relevantes para a sociedade. Não faz muito tempo, um governador disse que o INPA não fazia nada e quem da sociedade disse: não isso não é verdade. Não é o pesquisador que tem que dizer isso, é a sociedade, que do INPA se beneficia. É ela que tem que dizer: o INPA faz isso, isso, isso e isso. E é por meio da divulgação que a sociedade vai sentir que o INPA, como a universidade, como a Embrapa, são patrimônios da sociedade. Eventualmente, vocês estão lá hoje, mas, daqui a 50 anos, serão outras pessoas.

Como o sentimento que o paraense tem em relação ao Museu Goeldi? Nenhum político se atreve a falar mal do Museu Goeldi porque a socidedade vai reclamar. Na verdade, os políticos paraenses respeitam e reconhecem o MPEG como um patrimônio seu... Tem a ver com a maneira como se constituíram as relações da instituição com a sociedade. No caso, o MPEG é museu e, como tal, tem essa característica de abrir suas portas como um processo cultural...

É por aí...

Por que, sendo a Amazônia um campo de conhecimento tão fértil, a prática do jornalismo científico ainda é tão incipiente? Seis jornais diários, nenhum com editoria de C\&T ou de meio ambiente. Como avalia essa questão?

Estou concedendo essa entrevista para uma revista que é basicamente lida por cientistas. A primeira questão é, na ausência de processos mais consolidados, os próprios cientistas serem mais acessíveis aos jornalistas. Se eu pudesse dizer algo aos cientistas, diria que eles, ao serem pautados por um jornalista, não evitassem, que abrissem as suas informações. O jornalismo vende um produto que se chama informação. Se essa informação for demandada pela sociedade, os jornais vão abrir editorias de C\&T. Há um jornal que tem uma página semana dedicada à C\&T. Essa página deve ser bem ocupada. Por outro lado, não digo que tenhamos que levar nossos projetos para o jornal. Mas nós precisamos ter claras as nossas informações, dizermos o que efetivamente nós fazemos, como fazemos, para quem fazemos. Nós temos coisas maravilhosas sendo feitas, pelo pouco que eu conheci nesse tempo de FAPEAM. Coisas muito importantes para nossa sociedade, para o nosso desenvolvimento e que precisam ser melhor divulgadas. E aí tem que ter uma via de mão dupla: dos jornais, que se interessem em divulgar isso e também dos cientistas, que também queiram divulgar seu trabalho. Há cientistas que pensam que seu trabalho é tão importante que ele não deve vulgarizá-lo, passá-lo para o grande público. Nós temos tantas dissertações e tantas teses interessantes, trabalhos belíssimos. Um deles, é um trabalho muito bem escrito por uma amazonense, do interior, que foi minha orientanda, e que escreveu uma dissertação sobre as espacialidades e as escolas no interior. Ela fala na distância, como as crianças chegam à escola, e analisa o espaço etc., que é um trabalho para política publica na área. Essa dissertação teve uma grande repercussão aqui no ICHL [Instituto de Ciências Humanas e Letras, da $U F A M]$. Foram dois anos que a sociedade pagou o salário de professores, orientadores, bolsas para essa aluna, que compriu a sua obrigação realizando um exelente trabalho, mas parou aí, não escreveu um artigo para apresentar. Não deveria esgotar aí, deveria ser objeto de paper, de um texto para professores, gestores públicos, jornalistas etc. No caso dos gestores, poderia despertar reflexões do tipo: eu não posso fazer isso, não posso pegar escolas que tem 21 alunos, só porque a lei a manda que tendo menos do 21 alunos eu tenho que nucleá-la. Por que? Porque eu tenho que ver que estou na Amazônia e uma escola que vou fechar aqui para juntar com a outra lá pode estar a quatro horas de viagem. Eaí como vou por um garoto para ficar quatro horas na escola e quatro horas no barco, viajando. Esse é um exemplo concreto, que eu vivenciei. Agora, imagine quantas pesquisas importantes em outras áreas do 


\section{ACTA \\ AMAZONICA}

"A FAPEAM É UM PATRIMÔNIO NOSSO"

JOSÉ ALDEMIR DE OLIVEIRA: UM CIDADÃO AMAZÔNICO conhecimento e a sociedade não tem conhecimento dela. É preciso que a gente faça seminários de popularização. Por exemplo, na FAPEAM - e eu não sei até que ponto nós vamos ter pernas para ver isso concluído - o mestrando e/ou doutorando que recebeu recursos da instituição só termina a sua obrigação no dia que apresentar a sua dissertação ou sua tese em uma escola pública, ou numa associação, em alguma coisa pública, para não ficar apenas restrita àquele ritual da defesa.

Nós não podemos ignorar uma situação
que é histórica e recorrente: a dificuldade
de relacionamento entre cientistas e
jornalistas. São formações discursivas
diferentes e o sentido do que é notícia
para um, nem sempre é para o outro.
Daí, decorre a idéia, por parte dos
cientistas, de que há distorções, de que o
jornalista não compreendeu nada etc..
Sem contar que há, de fato, muitos
jornalistas mal preparados. Por outro lado,
há cientistas que não fogem da
linguagem hermética, não procuram - ou
não conseguem - passar os
conhecimentos de forma mais
simplificada. Enfim, isso dificulta o
processo de divulgação do
conhecimento científico via Imprensa?

Para o pesquisador, quando você pensa o pesquisador como aquela pessoa que vive da produção do seu conhecimento, uma página de jornal não vai acrescentar muita coisa ao seu currículo. Porém, isso pode acrescentar muita coisa se ele pensa de forma mais perene o seu trabalho e a instituição em que ele está inserido. Por que? Porque tão importante como ele divulgar, submeter as suas pesquisas a seus pares, porque é aí que vai estabelecer a sua meritocracia, é importante que ela submeta também a quem financia isso. Porque nós precisamos justificar, às vezes tinha conversas com pesquisadores e até com membros da equipe, que era assim: como se a FAPEAM fosse uma ilha, que está na lei que ela tem tanto do orçamento e que isso vai ser cumprido eu queira ou não. Isso vai ser cumprido no contexto político, em que entra deputado, governador, secretários etc etc., que é muito importante, sem isso eu não avanço. Mas se eu não tiver a capacidade de argumentar, a capacidade de convencer esses sujeitos de processos, aquela lei lá vai ser lei morta e não vai ter um centavo, como não teve de 1988 até 2003, que é quando começou de fato o financiamento, e nós esperneávamos. Então é a mesma coisa: se eu não consigo que a sociedade entenda que meu trabalho - mesmo que seja uma pesquisa de ponta, que eu esteja discutindo a alta tecnologia, o alto processo do mais complexo, DNA etc. -, se eu não for capaz de fazer que a sociedade compreenda isso, que isso é importante para ela, que esse meu estudo pode curar uma doença, pode ter inventado um produto que vai gerar emprego etc. Quando cortam nossa verba de ciência e tecnologia, nós reclamamos, mas a sociedade continua lá. Então, a divulgação é importantíssima e há meios para evitar problemas. Eu, por exemplo, nunca reclamei de distorção das minhas conversas nos jornais. O pesquisador tem mecanismos para fazer isso. É uma questão de negociar: olha eu te dou uma entrevista, mas quero que você coloque um boxezinho la que eu vou escrever, e faço texto para o jornalista. Agora, eu acho fundamental essa capacidade até para que nós nos valorizemos mais. O cientista tem que ser bem valorizado, bem remunerado etc. Para isso, tem que ser bem reconhecido na sociedade. E ele só vai ser reconhecido na sociedade se ela souber a importância de seu trabalho. Se não, não vai ser.

\section{Os cientistas no Brasil são reféns do Currículo Lattes? Ou seja, "eu só faço o que vai gerar reconhecimento no meu Lattes"...}

O Lattes é uma coisa relativamente nova, de no máximo uma década. Eu acho que já avançamos muito. Por exemplo, eu ouvi muitas discussões, nesse período que estava na FAPEAM, quando nós tivemos um ministro da Ciência e Tecnologia deputado e isso não foi um problema para os cientistas. Já tivemos época em que achava-se que o ministro tinha que ser cientista. Qual é a perspectiva de hoje? Tem que ser alguém com peso político para levar verba para ciência e tecnologia. Então, eu acho que daqui a pouco nós vamos entender que é importante não o cientista ser um militante político, não é isso. É o cientista ser um militante da ciência, da ciência na sociedade. Ou seja, eu vou falar exclusivamente do que eu conheço. Se alguém vem e diz: "teve uma rebelião na penitenciaria, qual a sua opinião?”. Eu digo: não entendo absolutamente nada disso. Eu entendo de questão urbana. $\mathrm{O}$ que isso tem a ver com a questão urbana? Aí, eu faço o gancho. Então, eu sou militante da minha área de conhecimento, não sou um militante político. O cientista tem que se preservar nisso. Agora, ele não pode se furtar de prestar contas do que ele faz à sociedade.

\section{E para ser presidente da FAPEAM, tem que ser cientista?}

Boa pergunta. Pode ser um cientista com uma boa visão política. Eu acho que nesse começo... Porque você pensa: no Ministério da Ciência da Tecnologia, ali, está tudo consolidado. Na FAPEAM, não. Tudo continua sendo feito. Então, eu creio que alguém que não é do meio, vivendo um outro lado, teria dificuldade. Eu não poderia estruturar a FAPEAM levando meus amigos para lá. Eu levo as pessoas que são competentes na sua área e que possam ser elementos de interconexão com os grupos. Porque nós somos uma comunidade muito exigente. 
O sistema de ciência e tecnologia tem que ter uma gestão política, mas uma gestão diferenciada.

\section{A política na academia é mais detalhista?}

É mais detalhista, é mais sofisticada, os nossos interesses são muito latentes. Deve haver sensibilidade de quem dirige e de ter também uma abertura direta com o pesquisador. Se encastelar na FAPEAM não é o caminho. Agora, respondendo à sua pergunta, eu acho que, independente de ser político ou cientista, tem que ser alguém comprometido com a causa publica, não se trata de ser um cientista, apenas. Se for um bom gestor sendo cientista, melhor. Agora, o gestor sendo político, ótimo. O exemplo do Eduardo Campos eu acho que é significativo, ele fez um bom trabalho. Um jovem que teve uma capacidade de ser compreendido muito rapidamente pelos cientistas. Houve uma insatisfação na época do Roberto Amaral, mas ele, Eduardo Campos, entrou e acalmou tudo... Aí agora entrou alguém mais da academia, embora venha de gestão há muito tempo, o [ministro Sérgio] Rezende, vamos ver. Mas independe, tem que ser um bom gestor, com sensibilidade, com cuidado com a coisa publica. Aquilo que antes deveria ser prática, hoje, parece que é mérito. Cuidar da coisa publica deveria ser condição sine qua non para qualquer gestor.

\section{O ex-ministro, deputado Eduardo Campos, foi um divisor de águas em relação à inserção de C\&T na pauta da grande imprensa nacional e internacional. Talvez, justamente, por ser político...}

E um bom gestor, com visão da importância de ciência e tecnologia para o avanço da sociedade.

\section{O senhor é militante do Partido dos Trabalhadores e mencionou que a sua ida para a FAPEAM foi fruto de uma costura política. Como avalia a atuação do governo de seu partido, em relação às políticas de gestão em C\&T?}

Acho que um primeiro avanço foi no sentido da descentralização de recursos. Nós tivemos, logo no primeiro ano do governo, propostas muito claras de descentralização, alguns passando pelas FAPs, e outros, por outras discussões, por outras instituições (no caso dos estados que não têm FAP). Foi o caso, por exemplo, de vários projetos do CNPq com a Finep e agora, de novo, com a Finep, que vai descentralizar recursos para eventos. Isso significa, em alguns casos, dobrar os recursos de ciência e tecnologia. No Amazonas, no período de 2003 e 2004, nós trabalhamos na perspectiva de um para um. O Governo Federal colocava um real, o Governo do Estado também. Foi assim com o PAPE, que um programa voltado para as empresas. Foi assim com primeiros projetos, foi assim com o DCR [Programa de Desenvolvimento Científico], aliás, no DCR o Governo Federal só paga a bolsa, a FAPEAM paga o resto, inclusive colocou $25 \%$ a mais na bolsa para atrair pesquisadores de outros estados. $\mathrm{E}$ isso fez com que recursos direcionados ao Amazonas fossem dobrados. Por um outro lado, eu creio que o grande mérito desse periodo, dos pesquisadores e dos gestores também, foi colocar a ciência e tecnologia em pauta. Antes, a ciência e tecnologia era pauta dos cientistas. E ela é uma pauta da sociedade nesses últimos tempos. Eu não posso dizer se os recursos aumentaram ou diminuíram, mas eu sei que em 2004, por exemplo, um levantamento rápido que nós fizemos na passagem do primeiro semestre para 0 segundo, e constatamos que todas as demandas de bolsas de pós-graduação do Estado do Amazonas tinham sido atendidas pelo CNPq, Capes e FAPEAM. Isso é algo inédito, reconhecido pelos pesquisadores. Eu nunca tive, no meu curso, todos os alunos que preenchessem os requisitos, com bolsa. Inclusive cursos que devolviam bolsas, que não tinha para quem oferecer. Depois, no ano seguinte, aumenta a seleção, aumenta o numero de cursos, a universidade está continuamente criando novos cursos, e aí, quando eu saí da FAPEAM, nós já tínhamos um déficit sanado de bolsas.

\section{E como está o Governo Lula em relação às políticas urbanas?}

Sobre isso eu minimamente posso falar. Essas políticas urbanas eram algo que, ao contrário de ciência e tecnologia, não tinham um sistema de financiamento, de infra-estrutura urbana, de planejamento urbano etc., e isso foi sendo criado. Estava sendo muito bem criado com a participação da sociedade civil organizada, com gente muito competente no Ministério das Cidades e que, infelizmente, foi destruído. Então, eu diria que se nós pensarmos hoje, julho a setembro de 2005, nós estamos do jeito que estávamos em janeiro de 2003, quando inicia o governo, em termos de políticas urbanas. É uma tragédia. Conseguiu se desmontar, em pouco mais de dois meses, uma 


\section{ACTA \\ AMAZONICA}

"A FAPEAM É UM PATRIMÔNIO NOSSO"

JOSÉ ALDEMIR DE OLIVEIRA: UM CIDADÃO AMAZÔNICO

estrutura que estava sendo montada a duras penas, com amplo participação de movimento social no Ministérios das Cidades. É um retrocesso brutal, envolve muitos recursos e, queiramos ou não, 75\% da população mora nas cidades. Então, nós tínhamos muita esperança de uma política rigorosa da área de saneamento urbano e que não está sendo executada.

\section{A desarticulação dessa política se deu em razão da crise por que passa o Governo?}

Sim, se deu agora, no segundo semestre, com a crise e com as mudanças, a saída do Olívio [Dutra] e da sua equipe. O atual ministro [Márcio Fortes de Almeida] é ligado ao Severino Cavalcante. Por aí, você tem uma idéia. Desmontou! As conferências de cidades são um caos. O Ministério Público assumiu em alguns estados, mas o MP não é para promover conferências. Então, não há participação popular e como você vai construir uma política sem a participação popular? Inclusive para a Amazônia. Nós estávamos com uma proposta muito interessante sendo costurada entre nós, aqui e o Pará, uma política consistente urbana, que estava avançada e que agora estamos todos sem saber o que fazer.

\section{E qual o seu sentimento, como intelectual e como militante, em relação à crise, aos escândalos no Governo Lula, um governo que ajudou a eleger?}

Primeiro, de perplexidade. Depois, é necessário avaliar com mais cuidado. Eu acho que o PT, assim como a política econômica, não inventou nada em várias áreas, inclusive na corrupção. Ela já existia e, infelizmente, o PT não foi capaz de frear. Esse é o primeiro aspecto. O segundo aspecto é que há uma diferença nesse processo, que aí eu acho que é questão de fundo, daquilo que os filósofos chamam de uma ética social e uma ética individual. Uma boa parte dessas pessoas, com uma ou outra exceção, é que elas não desviaram recursos, até onde sabemos, para colocar em seus bolsos. Elas desviavam por um projeto, entre aspas, coletivo, naquela perspectiva de uma ética social que justificasse você ter esses recursos para criar um projeto. A grande questão é que não existe uma ética individual separada de uma ética social. Ou, de outro modo, não existe uma ética social separada de uma ética individual. Não existe algo que seja construído coletivamente com a ausência do indivíduo, se pegarmos uma perspectiva da moral pura do [filósofo] Kant. Na verdade, o individuo é um ser que se constitui coletivamente. Portanto, não é diferente essa ética de que eu não faço algo individualmente porque isso é contra meus princípios, mas eu também não faço coletivamente se ela fere as normas da sociedade. Eu acho que essa é a questão fundamental e essa questão vem do início que eu falava: de que o PT não inventou. Tudo bem, o PT não inventou, mas ele não fez nada para estancar. Se eu entro na gestão publica, eu tenho que me coadunar às normas estabelecidas pela sociedade. $\mathrm{E}$, aí, houve o deslize e, infelizmente, sem um olhar mais aprofundado, concordando com Frei Beto, a esquerda conseguiu em dois anos e meio fazer o que a direita nunca conseguiu, que é desmontar - quiçá estejamos equivocados qualquer perspectiva de um projeto social mais perene. Quando você vê o neto do ACM [o senador Antônio Carlos Magalhães] como o grande paladino da moralidade, para onde é que nós vamos? Eu escrevi um texto, "Por quem ele chora", que eu retrato um pouco isso: a perplexidade. O mais cruel nesse processo todo é o pedagógico, da perda. É o tal do "está vendo? São todos iguais".

\section{Você falou que tinha esperança de que até $o$ final de 2006 a FAPEAM tivesse autonomia financeira. $O$ que alimenta essa esperança?}

Havia, há ainda, uma meta a ser alcançada, ou seja, gradativamente, você vai atingindo parte de um orçamento e criando, ao mesmo tempo, condições de que nós, institucionalmente, porque a questão é institucional, consigamos ter autonomia. Veja, o Estado o nosso tem dificuldade de criar uma fundação de direito privado. A FAPEAM é uma instituição de direito público, que significa recursos do Tesouro. Então, neste ano de 2005, já está negociada toda a liberação de orçamento. Claro que a mudança atrasou um pouco até que as pessoas tomassem pé da situação, mas já era uma meta estabelecida para quatro anos, para iniciar um segundo governo ou outro governo com autonomia financeira. Se fosse o caso, fazer um escalonamento orçamentário até atingir o $1 \%$ que, em valores de hoje, representaria 38 milhões de reais. Então, uma autonomia financeira poderia até pensar em um re-escalonamento disso ( 0,50 num ano; 0,75 no outro; 0,90 no outro e $1 \%$ no outro) e aí ter aquilo como uma autonomia da mesma forma que os outros poderes. Ou seja, a FAPEAM teria, dentro do Poder Executivo, uma autonomia que tem, por exemplo, o Poder Legislativo. E teria um Conselho Superior e um Conselho Fiscal muito mais vigilantes na gestão, e uma câmara que cuidaria dos processos de avaliação.

\section{E no seu entender as coisas estão efetivamente caminhando nesse rumo ou ainda falta muito?}

Quando eu optei sair da FAPEAM, eu saí mesmo. Aliás, preciso até visitar o site da FAPEAM. Mas pelo menos até o final do ano eu não saberia dizer como está sendo conduzido esse processo. Entretanto, eu sei dizer que a pessoa que foi escolhida para a direção da FAPEAM é uma pessoa altamente qualificada, responsável e muito comprometida com a coisa pública e com a produção do conhecimento, que é o professor Odenildo Sena. 


\section{ACTA AMAZONICA}

"A FAPEAM É UM PATRIMÔNIO NOSSO"

JOSÉ ALDEMIR DE OLIVEIRA: UM CIDADÃO AMAZÔNICO

\section{Certamente. A pergunta saber se existe ainda necessidade de articulação política institucional?}

Nós vamos para um processo eleitoral. Então, assim como nós arrancamos o compromisso de implantar, vamos arrancar dos candidatos o compromisso público da autonomia geral e irrestrita. E aí, vamos fortalecer a escolha dos dirigentes, para criar algo consolidado.

\section{Como é o caso da FAPESP, entra governo e sai governo e a FAPESP está lá...}

É verdade. Há um modelo que eu tenho muita esperança de que se consolide agora, que é a FAPEMIG. Eles estão muito bem. E não é difícil você convencer com gestão competente, com os pesquisadores participando, não é difícil você conseguir isso, e o atual governador me impressionou muito nesse convívio de dois anos e meio. Eu saí de lá muito bem impressionado com a possibilidade de ouvir dele, enfim, eu saí com uma boa impressão e tenho certeza de que isso é possível, de que nós lutemos pela consolidação e autonomia da FAPEAM.

\section{Do ponto de vista prático, isso depende da Assembléia Legislativa?}

Depende. Depende de uma série de caminhos institucionais a serem seguidos. E não esqueçamos que é a mesma gestão da Secretaria de Ciência e Tecnologia, da qual a FAPEAM faz parte. A FAPEAM está nesse sistema e há de se destacar o trabalho realizado pela professora Marilene Corrêa.

\section{Poderia falar um pouco sobre o papel da secretária (de Ciência e Tecnologia) \\ Marilene Corrêa nesse processo que viveu na FAPEAM.}

É muito importante, com autonomia, com respeito ao que nós fazíamos, mas com a responsabilidade de cumprir as políticas da Secretaria, que, na estrutura governamental, é de onde emanava as políticas de C\&T no Estado. A FAPEAM é uma executora. E é bom que seja assim. É bom que ela não esteja no planejamento dessa estrutura, mas que ela esteja na execução. Ou seja, as linhas gerais mesmo têm que ser traçadas pela Secretaria. E nós tivemos uma boa convivência.

No dia a dia da pesquisa, o pesquisador reclama muito, e cada vez mais, da quantidade de relatórios que deve fazer, uma série de papéis que o impede de

\section{fazer o que gostaria, que é a pesquisa. Como pesquisador, você certamente também sente isso. Qual foi a contribuição da FAPEAM para atenuar esse problema? Houve essa preocupação?}

Poderíamos ter uma opção de fazer o financiamento via institucional, ou seja, articulado com a instituição, mas o dinheiro vai para o pesquisador. Acho que isso já era uma forma de valorizar. A outra questão é a seguinte: o grande problema que as instituições de pesquisa estão com dificuldades seriíssimas de infra-estrutura, de pessoal etc. E uma face não vai, pelas limitações inclusive legais, ela não pode financiar, por exemplo, pessoal para a pesquisa no sentido de que não seja pesquisador. Ou seja, você pode ter lá um aluno bolsista. Mas é premente que nós discutamos nos nossos editais, por exemplo, ter um AT (auxiliar técnico) que fosse um secretário, um que prestasse a conta, porque o processo de financiamento da FAPEAM não termina na FAPEAM, termina nos Tribunais de Contas. E o Tribunal de Contas não quer saber se o dinheiro foi para o pesquisador ou para construir uma ponte. Ele quer saber se os papéis estão lá direitinho e como foram enpregados. Até me surpreendeu positivamente, em alguns aspectos, a boa vontade do Tribunal de Contas em razão de que estávamos começando. O importante era o seguinte: foi empregado no projeto? Se foi, estava ok. Porque na burocracia mais pesada, se você pediu para comprar esse copo e comprou o gravador, devolve o dinheiro. Conosco havia uma certa flexibilidade. Claro que isso tem um limite. Mas esse é um grande problema, que se não for bem equacionado, não vai resolver. Agora, eu acho que isso tem que ser melhorado no contexto mais geral das instituições também. As instituições, em algum casos, quando os pesquisadores recebiam os recursos, tinham limitações. Por exemplo, no início eu era meio contrário a financiar automóveis, mas resolvemos experimentar. A instituição que deu ok, concordou, não queria ser responsável pela manutenção e emplacamento dos veículos. Foi quando pedimos que devolvessem à FAPEAM. De repente, resolveram assumir a responsabilidade e o problema foi equacionado, porque o pesquisador precisava da condução, e nós só financiamos quando entendíamos que era necessário. Pois bem, é um longo processo das instituições financiadoras e das instituições captadoras de recursos. O que acontece é que nós não vamos resolver o problema da ciência e tecnologia só com o financiador. Achar que a FAPEAM, ou CAPES ou o CNPq, resolverão, porque têm limites, porque lidam com recursos públicos.

E aí o pesquisador vai continuar tendo
que buscar várias fontes de
financiamento para manter os seus
projetos. Você acredita que a curto prazo




\section{ACTA AMAZONICA}

\section{o pesquisador vai parar de reclamar dos relatórios?}

Não, não, nós vamos continuar reclamando, eu já estou reclamando. Já viu algum pesquisador dizer que não precisa mais de recursos? Então, nós vamos reclamar e é bom que continuemos para irmos nos aperfeiçoando. Por exemplo, eu acho necessário que a gente inclua nos projetos um valor que garanta a contratação de uma pessoa para o grupo, que fique responsável por isso. Não é o pesquisador que deve colar notas fiscais, fazer o burocrático.

\section{Você mencionou que no programa Jovem Cientista todos recebiam bolsa. Quando fui coordenador de um projeto, contratei uma pessoa para essa função e repassei a bolsa do coordenador integralmente para ela.}

Pois é. Nós temos que discutir, em nosso projeto, assim: eu posso contratar um bolsista mestre, no valor de tanto, então, eu vou poder contratar alguém de gestão. Agora, o pesquisador tem que ter cuidado, porque ele é o responsável por tudo, tem que ser alguém da confiança dele. É necessário que nós criemos essas condições e que as instituições financiem um bolsista por um período do projeto porque senão é complicado. O pesquisador capta recursos, gesta os recursos, paga a pesquisa, normalmente coordena o grupo, ou seja, acaba fazendo tudo.

\section{Vamos falar sobre as tecnologias de ponta. Você certamente, é uma das pessoas, aqui no Amazonas, que têm uma visão ampla sobre a capacidade instalada da pesquisa nas instituições da Amazônia. Na sua avaliação, qual é a capacidade que as nossas instituições têm de contribuir, efetivamente, para pesquisas em tecnologias de ponta?}

Bem, na área de bigh-tech mesmo, ligada à eletrônica, eu creio que nós estamos iniciando um processo muito interessante com alguns institutos privados desse sistema $P \& D$ ligado aos $5 \%$ das empresas de informática e, agora pela primeira vez, eu vejo com muito bons olhos a aprovação de um projeto de C\&T em um grupo aqui da [Faculdade de] Tecnologia muito produtivo. Nessa área biológica, eu creio que nós temos uma boa acumulação no INPA, com a necessidade de alguns investimentos pontuais, bem direcionados, de equipamentos, em grupos que possam efetivamente dar resposta, desde que articulados com grupos das ciências biológicas, da biotecnologia ligadas à universidade. E aí o processo que já seria após isso, e que eu acho que não foi muito bem entendido, até pelo exagero do empreedimento imobiliário, digamos, que era o papel do CBA [Centro de Biotecnologia da Amazônia]. Esse papel seria esse momento em que você desenvolve processos de investigação, pesquisas, e que chega a esse produto precisando dar garantias de benefícios a esse grupo que gerou esse conhecimento, mas esse grupo não pode ser aquele grupo que vai colocar no mercado esse produto ou esse processo. Entao, eu vejo que nós ainda necessitaríamos de ver pontualmente onde estão os gargalos infra-estruturais de equipamentos de ponta que possivelmente poderiam ser compartilhados com a nossa instituição. $\mathrm{Na}$ área de biotecnologia, nós poderíamos verificar isso pontualmente, onde estão esses gargalos; e nós temos condições para isso, e, na área de tecnologia, por exemplo, da micro-eletronica, um nicho que nós pudessemos desenvolver. Porque a geração de conhecimento independe de você estar em um grande centro. É só você criar a infra-estrutura e a condição de financiamento, para atrair pesquisadores de ponta. Quem financia hoje, por exemplo, boa parte das bolsas do CBA é a FAPEAM. Boa parte não, totalmente. E tem cinco ou seis pesquisadores de ponta e que a permanência desses pesquisadores por um certo período, trará, com certeza, resultados muito promissores para o nosso Estado nessa área de geração de produtos e processos. Quando eu digo que não foi muito entendido, porque confundia-se qual era o papel da CBA e qual era o papel do INPA, da Embrapa, da universidade.

\section{Mas isso começou confuso...}

Começou confuso porque, na minha opinião, nós tínhamos que primeiro fazer o institucional. Não necessariamente um prédio daquele porte, mas uma estrutura que desse conta disso, ou seja, de você chegar e identificar claramente nichos no INPA, na Embrapa, na universidade e em outras instituições, tipo: aqui, nós precisaríamos de tal equipamento de ponta, que custa caro, que nós podemos trabalhar em rede e que isso nós podemos estabelecer uma meta na geração de determinado conhecimento a médio prazo. Agora, nós vamos criar uma estrutura, juntando esses institutos, que vai pegar a geração desses conhecimentgos e vai transformar num produto. Não precisava construir aquele prédio, poderia ter reforçado as instituições. Como sempre, no Brasil, nós fizemos um prédio muito bonito e tudo, mas até hoje nós não sabemos como vai ser a gestão.

\section{Essas redes têm condições de se tornar funcionais aqui no Estado?}

Com certeza. A rede proteômica, por exemplo, que tem financiamento da FAPEAM, é muito promissora. Tem o grupo da pesquisa biotecnológica articulando a cadeia produtiva do guaraná, que também é muito promissor. E, antes disso, o mapeamento do código genético do guaraná. E aí também muito promissor o grupo da malária, que está iniciando. Eu sei que quando estávamos lá, estávamos fomentando isso, fizemos 


\section{ACTA AMAZONICA}

"A FAPEAM É UM PATRIMÔNIO NOSSO"

JOSÉ ALDEMIR DE OLIVEIRA: UM CIDADÃO AMAZÔNICO contato com o Esper Cavalheiro, e eu já sei que a coisa já está andando. Já mandaram um projeto de um grupo de célulastronco, cujo centro é o Hemoam, envolvendo pessoas da UFAM, pesquisadores do INPA, também muito promissor. Enfim, em ciência e tecnologia eu aprendi duas coisas no período em que estive na FAPEAM: você tem que focar metas. É claro que ao focar metas nesses nichos que eu falei, eu vou desagradar muitos outros que vão estar fora. Mas é ali, você indentificar as competências, grupos promissores e investem pesado nisso. E não pode ser pouco investimento não. É investimento pesado. Ninguém vai superar essa desigualdade - se há um setor onde se expressa essa desigualdade nacional é na ciência e tecnologia. Nós não recebemos recursos porque não temos doutores e não temos doutores porque não recebemos recursos.

\section{É aquela famosa descrição dos $8 \%$ da população...}

Isso. Nós tínhamos que atingir isso. Se eu tenho x-porcento da população eu vou investir. Agora, eu escolho determinadas áreas que já têm uma certa capacidade local, por exemplo, nessa area de piscicultura, de pesca, nós temos uma boa competência instalada e é um setor estratégico para o Estado. Caberia investir nisso.

\section{Ainda sobre as tecnologias de ponta, mas agora voltadas para a resolução dos ditos grandes problemas da Amazônia, que são o desmatamento, a sustentabilidade, migração etc. Qual a sua avaliação desse quadro?}

Eu falo do Estado do Amazonas. Primeira coisa, precisamos investir pesado na criação de grupos fortes na área de ciências humanas, para que sejamos capazes de reunir e trazer gente que possa dar respostas a algumas áreas de geração de conhecimentos, ainda, da gestão do território, da área de lingüística. Nessa área, por sinal, nós temos que mapear todas as línguas que temos, antes que desapareçam. Creio que aí dá uma comparação muito interessante entre o [Museu] Goeldi e o INPA. Acho que o INPA foi muito para a área natural, a universidade, por seu turno, tem uma missão diferente, porque aqui na universidade nós não somos pesquisadores, nós somos professores e pesquisadores. Temos ensino, extensão e pesquisa. Pesquisa, o básico, é verdade. Se bem que hoje isso está mudando muito. Quando a gente pára aqui na universidade, só pára o ensino, a gente continua fazendo o resto. O ensino é o primo pobre hoje em dia. Mas eu acho que é fundamental, no caso do Amazonas, nós termos grupos que sejam referência nacional nessa area de ciências humanas. Principalmente se nós tivéssemos um tema gestão de territórios, porque nesse tema nós trabalharíamos a questão do desmatamento, do aumento da população, dessas relações entre a modernização e as dimensões pretéritas, enfim, o eixo seria esse. E aí, nós temos algumas conversas com o Arnaldo [Carneiro, pesquisador] do INPA, no sentido de a gente pensar em alguma coisa, de um núcleo de pós-graduação nessa área de gestão de território.

\section{O pesquisador do INPA também é professor, também orienta e é muito cobrado por isso. Mas queria entrar em outra questão, que está relacionada a esse tema, que são as bolsas DCR. Para fortalecer os grupos de pesquisas ou a gente forma o pessoal em nível local ou atrai pesquisadores formados em outros centros. E o Programa DCR é um programa que cumpre um pouco essa função, na medida em que disponibiliza cursos para pesquisadores qualificados, jovens doutores. Eu queria saber qual é a sua avaliação do programa DCR da FAPEAM, no sentido de suprir essa necessidade?}

A grande questão é que uma política de ciência e tecnologia não está separada de uma política pública mais geral. O programa DCR é muito importante, mas ele tem que ser pensado de uma perspectiva um pouco mais ampla. Você não vai resolver o problema de ciência e tecnologia em regiões como a nossa só com bolsas. Não vai. Porque é limitado, a perspectiva é de três anos apenas, ela é muito importante, mas tem que ser acoplada a duas outras políticas. Uma, a política de fortalecimento das instituições. Porque quando eu discuti a questão da DCR, nós fomos de instituição em instituição com o dirigente máximo. Fiz isso com a universidade, com o INPA, com a Embrapa, com a UEA etc. Reuni com o reitor para falar sobre o programa, sensibilizado da seguinte perspectiva: recebe DCR quem efetivamente tiver perspectiva de absorver esse DCR, que era para criar mecanismo de o pesquisador vir para a Amazônia, para o Amazonas, e, se der tudo certo, ele permanecer. E não com a perspectiva de que três anos depois ele vai voltar.

Segundo, com uma política de formação de recursos humanos locais. Nós não podemos ficar só na dependência de trazer os doutores de fora. Primeiro que algumas áreas são impossíveis de atrair pessoas. Dou-lhes um exemplo: nesses dois anos e meio de FAPEAM nós não trouxemos ninguém para a universidade na área de ciências humanas, ninguém. Por que? Porque é uma área que, via de regra, a pessoa tem uma remuneração pequena, não é aquele professor que recebe muito, e a maioria já está empregada no Brasil. Então. nós temos que formar essa gente aqui. Agora, é algo necessário, 


\section{ACTA \\ AMAZONICA}

"A FAPEAM É UM PATRIMÔNIO NOSSO"

JOSÉ ALDEMIR DE OLIVEIRA: UM CIDADÃO AMAZÔNICO extremamente necessário, e o esforço do governo do Estado, por meio da FAPEAM, foi significativo, primeiro com $25 \%$ da bolsa e depois com toda a infra-estrutura, o grupo, nós criamos condições para esse pesquisador não ser um peso ao grupo. Então, ele chega lá, é o líder do grupo, e, além de levar o equipamento básico, com 50 mil pelos três anos, ele levava o mesmo valor para o grupo. Ou seja, ele não era um peso ao grupo, ele era alguém que se agregava ao grupo. Agora, sem o fortalecimento das instituições e sem formar gente aqui, o DCR é inócuo. Porque está vindo sempre muita gente jovem, não está vindo gente de ponta. O CBA é uma exceção.

\section{E está vindo ou estão devolvendo bolsa?}

Não que eu saiba. Primeiro, era um programa razoavelmente tão bom que as pessoas desconfiavam dele. Então, as demandas foram crescentes. A primeira vez nós tivemos cinco, na segunda dobrou. Eu sei que, hoje, a FAPEAM, quando eu saí de lá - aí tem o problema, que essa descentralização não é ampla, geral, e irrestrita, o CNPq ainda toma para si, os seus comitês ainda têm a última palavra, para se reunir cada comitê, para você ter uma idéia, quando eu estava na FAPEAM, nós mandamos a última remessa. Eu saí em 30 de junho e até agora ainda não chegou o resultado, demora. Mas, hoje, a FAPEAM tem lá, para você ser contratado, três vezes mais ou duas vezes mais que o número de bolsas que ela tem. Mas o CNPq garantiu que vai mandar, porque tem outros estados que não preencheram sua cota. O Amazonas vai preencher sua cota dobrado. Agora, eu ainda acho que tem alguns problemas instituicionais, muitos problemas institucionais nos resultados. Porque, vejam, a instituição tá recebendo um pesquisador a custo zero. Custava a instituição - e essa era a perspectiva que eu tinha com os dirigentes - de dar uma contrapartida. Se nós ficássemos de braços cruzados, só teria a bolsa do CNPq, como em muitos estados. Nós criamos $25 \%$ a mais e demos, salvo engano, três bolsistas e 50 mil reais para cada grupo e 50 mil reais para o líder do grupo. Isso é recurso orçamentário da FAPEAM. Eu imaginava que as instituições dissessem: vamos dar alguma coisa para ajudar a moradia do pesquisador. Ela recebe, tem lugar que o pesquisador tem dificuldade em se inserir. Então, resumindo, sem uma política de fortalecer as instituições de modo que abram perspectivas para a contratação de novos pesquisadores e sem formar recursos locais o DCR é inócuo. Só com gente de fora, por meio de bolsas, acabou sai. Não só isso. Por exemplo, a nossa perspectiva era de na universidade, quando se abriu vagas, a prioridade fosse para os que tivessem DCR. Isso nem entrou em discussão.

\section{Se tentou fazer um encadeamento institucional...}

Mas havia uma discussão: não faz aqui não, porque aqui tem pesquisador que vai durar três anos. Olha a mentalidade! Sabe onde funcionou admiravelmente bem? Nas instituições do Estado. A Fundação de Medicina Tropical foi um exemplo, inclusive nós registramos junto ao CNPq. E tem mais, por conta desse incentivo, nós garantimos o seguinte: se a instituição fizer um concurso e o pesquisador passar, nós asseguramos, durante os três anos do projeto, que o recurso das bolsas, recurso do custeio, sejam garantidos. Nós vamos garantir até completar os três anos, os três bolsistas que nós nos comprometemos. Dissemos isso ao CNPq. A bolsa do CNPq era garantida por seis meses e nós dávamos a complementação. Então, se o pesquisador fosse absorvido pela instituição onde ele estava, ele já entrava com o enxoval (risos). Durante seis meses, ele recebia bolsa. Só quem fez isso, o Hemoam, os que fizeram o concurso do Estado. O pesquisador do Hemoam passou no concurso, porque era bem preparado, e foi garantido, e os pesquisadores da Fundação de Medicina Tropical passaram e foram garantidos. Mas eles abriram o concurso para aquela área. Eles não foram nessa de que ninguém vai abrir porque aqui tem muita gente. O trabalho seríssimo de uma pesquisadora colombiana sobre malária na gestação, belíssimo, uma coisa linda, de emocionar. E a moça do Hemoam também muito competente, não lembro o trabalho dela.

\section{Jovem Cientista Amazônida, você já falou bastante, mas trata-se de um projeto que é inédito, uma experiência ousada em nível mundial, não?}

Sem dúvida. Agora, nós temos que mostrar a necessidade de se fazer um novo edital. Era o único edital que eu queria abrir este ano. Eu acho que eles vão abrir para dar tempo de todo mundo fazer o seu projeto, aberto àqueles que participaram e que, se foram bem avaliados, com certeza terão pontos a mais que os outros, e novos projetos, para começarem a executar a partir de março do próximo ano. Eu tenho quase certeza de que isso vai ser feito. $E$ havia a perspectiva de abrir para comunidades extrativistas, essas comunidades de preservação.

\section{A avaliação do projeto pelo pessoal da comunidade que trabalhei, foi acima de qualquer expectativa. A gente teve mais dificuldade de participação em projeto de pesquisadores do que do pessoal da comunidade. Pesquisador às vezes não tem tempo de orientar alunos de ensino fundamental, terminando por escalonar suas prioridades, e isso acaba indo lá pra baixo.}

Depois que eu cheguei aqui, de vez em quando aparece um colega para me visitar. Se há uma coisa positiva que eu fiz na FAPEAM foram as amizades. Eu fiz muitas amizades, inclusive com pessoas de outras áreas. Já teve um professor de ponta da área de biológicas, que já veio aqui conversar comigo, propondo 
fazer um projeto juntos, caso haja um JCA. Ele disse: eu quero fazer isso, isso e isso lá na comunidade, vou ensinar para os garotos. E eu disse: ótimo, se tiver, nós vamos fazer. Então, eu acho que isso também é um processo.

A FAPEAM tinha projetos para além da contribuição que ela pode dar, na geração de conhecimento. Um: boa parte dos pesquisadores - o percentual de pessoas que tiveram acesso ao primeiro projeto por meio da FAPEAM é bastante significativo - também aprendeu a lidar com prestação de contas, com processos, etc.

Dois: o processo, que é um processo educativo lindo. Esse processo educativo leva, também, à valorização de projetos simples, baratos, mas com uma grande repercussão nas comunidades. E três: a educação do próprio Estado. Quando comecei as primeiras inscrições na FAPEAM com gestores públicos, eles pensavam que bolsa era isso [aponta para uma bolsa de mão]. Eles não sabiam que bolsa era salário, quer dizer, não é bem salário, mas foi mais fácil explicar assim, que tinha um cronograma. Então o JCA, quando eu saí de lá, eu pedi das pessoas para participar quando tivesse uma avaliação, porque da outra avaliação eu não participei. Eu estava fora. E aí teve uma que me convidaram até, mas eu estava tão fragilizado, que eu não iria conseguir. Porque oJCAé emociante. Não tem uma palavra. Ele é aquilo que nos possibilita estabelecer o nãoracional em algo tão racional que é a ciência e a tecnologia.

\section{É impressionante. No Tupé, nós começamos com sete alunos e agora, no final, quando a gente perguntou aos estudantes quem gostaria de participar, se houver um novo edital, apareceram mais de 30 alunos...}

\section{E como foi a experiência em Paris, que iria nos contar?}

Na primeira vez eu não fui, porque não podia viajar, e na segunda eu fui. Havia dois alunos jovens, não eram necessariamente crianças, era um professor e um jovem de 15 a 16 anos, e todo mundo chegava lá na palestra muito cheio de parafernália tecnológica. Nesse dia, o auditório tava cheio, era um período muito ruim de Paris esvaziada, porque era férias. $E$ aí eles vão fazer o que eles aprenderam. Em vez de cada um falar, eles estabelecem um diálogo entre eles. Um perguntava: o que você aprendeu? O outro respondia: eu aprendi a identificar as madeiras. E que madeiras você identificava? Essa, essa e essa. E que madeira era essa? qual o nome científico? E como é que a gente identifica? E como é que se media? Um diálogo entre eles fazendo graça um com o outro. Terminou, todo o mundo aplaudiu de pé. Assim, só eles, na simplicidade, e a capacidade que tiveram de inventar um diálogo. Fugiram completamente daquilo que já tinha sido apresentado. E não era o primeiro dia, que eles podiam ter dito assim: olha, temos que fazer igual aos outros. Mas não... Inesquecível.

\section{A UFAM cresceu muito na pós-graduação, nos últimos anos, houve participação da FAPEAM nesse processo?}

Eu creio que, nessa última fase, esse já é um processo em curso. Dizer que isso é responsabilidade só da FAPEAM é exagerado. Agora, eu diria que podemos atribuir, especialmente, a avaliação que alguns cursos tiveram, aos recursos da FAPEAM. Porque a FAPEAM financia bolsas e dá um bom custeio aos cursos, o que possibilitou melhorar a infra-estrutura do curso, fazer publicação de revistas científicas, etc. Mas já era um processo em curso na UFAM, que não veio dessa administração, mas de outras, e é um processo institucional, e creio que vai ser continuado e é necessário. Às vezes eu lembro que tinha uma discussão de que determinadas áreas do conhecimento não precisava ser criada na UEA porque já tinha na UFAM. Bobagem. Principalmente, porque se trata de instituição pública. Se tivéssemos uma outra instituição pública criando cursos de pós-graduação de qualidade, seria muito bom. O que nós não podemos é prescindir da qualidade, temos que ter cursos de qualidade. Aí, creio que na nossa área de ciências humanas e sociais é premente a criação de cursos, pelo menos de mestrado, na própia minha área de geografia, na área de antropologia, de lingüistica, e nós, na área de humanidades, criarmos um doutorado. Não sei como é que estão as tratativas com o INPA, mas o ideal seria criarmos um doutorado interinstitucional, voltado para o entendimento de uma natureza amazônica, não a natureza natural, mas uma natureza da exegese da Amazônia, seus processos da sociodiversidade e da biodiversidade, e da cultura desses povos, porque nenhuma região é construída pela natureza, apenas. É construída, também, pela sua cultura. Na área de saúde, nós demos um avanço interessante. E aí teve, muito modestamente, a participação da FAPEAM garantindo que, em sendo aprovado um projeto, haveria financiamento. A criação de um projeto interinstitucional e interestadual, que é o mestrado Saúde e endemias na Amazônia, da Fiocruz e UFAM, aqui no Estado, da UFPA e do instituto Evandro Chagas, em Belém, e trazendo gente de toda a região. O curso se dá concomitantemente em Manaus e Belém, os alunos podem, em determinado momento, fazer intercâmbio. É uma experiência fantástica, eu fiquei muito satisfeito de a gente ter contribuído minimamente para isso, mas foi um esforço das instituições. Porque é assim: à FAPEAM cabe o papel de dar uma boa parte dos recursos. Enfim, eu acho que estamos no caminho, é necessário que a gente pense grande em termos de Amazônia, em termos da gestão de ciência e tecnologia, da formação de recursos humanos aqui, sem achar que temos que virar um gueto. Nós temos que fazer intercâmbio, continuar mandando gente para fora, trazer gente de fora, mas formando o nosso pessoal também. 